\title{
Low Temperature Synthesis of Liquid Hydrocarbons from Syngas on Composite Catalysts of Pd-doped Cu-Cr-Zn Mixed Oxides and an H-ZSM-5 Zeolite
}

\author{
Tomoyuki InuI*, Takashi Hagiwara, Osamu Yamase, Kazuichi Kitagawa, \\ Hiroki Yamagughi, and Yoshinobu Takegami \\ Department of Hydrocarbon Chemistry, Faculty of Engineering, \\ Kyoto University, Sakyo-ku, Kyoto 606
}

(Received August 13, 1984)

\begin{abstract}
Synthesis of liquid hydrocarbons from syngas was studied at relatively low temperatures, below $300^{\circ} \mathrm{C}$, using bifunctional composite catalysts composed of low-temperature type methanol-synthesis catalysts of Pd-doped $\mathrm{Cu}-\mathrm{Cr}-\mathrm{Zn}$ mixed oxides and an H-ZSM-5 zeolite. As a source of $\mathrm{Zn}$ component of the methanol synthesis catalyst, freshly prepared $\mathrm{Zn}(\mathrm{OH})_{2}$ from $\mathrm{Zn}\left(\mathrm{NO}_{3}\right)_{2}$ was more suitable than a commercial $\mathrm{ZnO}$ powder for higher hydrocarbon yields. Oxidation and succesive reduction (O-R) treatments of the composite catalysts were carried out at $400^{\circ} \mathrm{C}$ and in the range of from 400 to $800^{\circ} \mathrm{C}$. When the reduction temperature of O-R treatment was $600^{\circ} \mathrm{C}$, the performance of the composite catalysts was appreciably improved. Syngas $\left(\mathrm{H}_{2} / \mathrm{CO}=2\right)$ was converted to hydrocarbons, dimethyl ether, and $\mathrm{CO}_{2}$ with selectivities of $44.1,1.4$, and $54.5 \%$, respectively, at $35.8 \% \mathrm{CO}$ conversion at $290^{\circ} \mathrm{C}, 20 \mathrm{~atm}$, and 6,000 hourly space velocity. The space-time conversion of $\mathrm{CO}$ to liquid hydrocarbons $\left(\mathrm{C}_{\mathbf{4}} \sim \mathrm{C}_{11}\right)$ and the corresponding selectivity were $9.5 \mathrm{~mol} / l \cdot \mathrm{h}$ and $61.4 \%$, respectively. By lowering the $\mathrm{H}_{2} /$ $\mathrm{CO}$ ratio of syngas from 2 to 1 , the liquid hydrocarbon selectivity increased to $68.4 \%$ whereas the space-time conversion of $\mathrm{CO}$ to liquid hydrocarbon decreased.
\end{abstract}

\section{Introduction}

Conventional Fischer-Tropsch reaction obeys Shulz-Flory carbon-number distributions of the products resulting in low gasoline selectivity. After the success in selective gasoline synthesis from methanol using ZSM-5 zeolite ${ }^{1) ~ 4)}$, Mobil's researchers applied this shape selective zeolite, combining it with methanol-synthesis catalysts (MSC) to direct synthesis of high octane-value gasoline from syngas. ${ }^{5)}$ Since this work, syngas to gasoline (STG) reaction using this kind of composite catalysts has been studied by many researchers. ${ }^{6) \sim 13)}$ STG reaction via methanol is theoretically advantageous for its nontrivial polystep mechanism ${ }^{14}$ ) which enables overcoming thermodynamical conversion restrictions of methanol synthesis. However, at the present stage, product distribution is inferior to that of methanol conversion over ZSM-5 catalyst (MTG), and there is still much room for improvement. In our previous work ${ }^{12)}$, the effect of modifying $\mathrm{ZnO}-\mathrm{Cr}_{2} \mathrm{O}_{3}$ industrial methanol-synthesis catalysts on the performance of the composite catalysts was investigated.

* To whom correspondence should be addressed.
Palladium-doping and O-R treatment were effective for increasing gasoline yields. However, the catalyst activity was low, requiring such high temperature as $381^{\circ} \mathrm{C}$ to obtain satisfactory yields of hydrocarbons. Therefore, in this study, low-temperature type $\mathrm{Pd}$-doped $\mathrm{Cu}-\mathrm{Cr}-\mathrm{Zn}$ catalysts were adoped as MSC, and they were combined with highly active H-ZSM-5.11),12) Using these catalysts, syngas conversion was examined under considerably mild reaction conditions around $300^{\circ} \mathrm{C}$ and $20 \mathrm{~atm}$.

\section{Experimental}

\subsection{Preparation of Low-temperature Type Methanol-synthesis Catalysts}

Palladium-doped Cu-Cr-Zn methanol-synthesis catalysts were prepared using the method reported in the literature ${ }^{15)}$ with some modification. The precipitate of $\mathrm{Cu}(\mathrm{OH})_{2}$ from $\mathrm{Cu}\left(\mathrm{NO}_{3}\right)_{2}$ using $\mathrm{NH}_{3}$ aq. as the precipitant at $\mathrm{pH}=7.9$ was kneaded with $\mathrm{Cr}_{2} \mathrm{O}_{3}$ and the mixture was allowed to dry at $75^{\circ} \mathrm{C}$ for $4 \mathrm{~h}$, before grinding. An aqueous solution of $\mathrm{Pd}\left(\mathrm{NO}_{3}\right)_{2}$ was mixed with $\mathrm{ZnO}$ powder, varying its amount, followed by calcination in air at $400^{\circ} \mathrm{C}$ for $4 \mathrm{~min}$. For preparing $\mathrm{Zn}$ component 
Table 1 Composition of Catalysts Used

\begin{tabular}{|c|c|c|}
\hline Symbol & $\begin{array}{l}\text { Catalyst Composition } \\
\text { (atomic ratio) }\end{array}$ & $\begin{array}{l}\text { Source of } \\
\mathrm{Zn}\end{array}$ \\
\hline $\begin{array}{l}\mathrm{N} \\
\mathrm{M} \\
\mathrm{M} \\
\mathrm{M}\end{array}$ & $\begin{array}{l}\mathrm{Au}: \mathrm{Gr}: \mathrm{Zn}=2: 1: 2 \\
\mathrm{iu}: \mathrm{Cr}: \mathrm{Zn}: \mathrm{Pd}=2: 1: 2: 0.012 \\
\mathrm{iu}: \mathrm{Cr}: \mathrm{Zn}: \mathrm{Pd}=2: 1: 2: 0.05 \\
\mathrm{iu}: \mathrm{Gr}: \mathrm{Zn}: \mathrm{Pd}=2: 1: 2: 0.1 \\
\mathrm{iu}: \mathrm{Cr}: \mathrm{Zn}: \mathrm{Pd}=2: 1: 2: 0.1\end{array}$ & $\begin{array}{c}\mathrm{ZnO} \text { powder } \\
\text { "1 } \\
\text { " } \\
\mathrm{Zn}\left(\mathrm{NO}_{3}\right)_{2}\end{array}$ \\
\hline
\end{tabular}

from $\mathrm{Zn}\left(\mathrm{NO}_{3}\right)_{2}, \mathrm{Pd}\left(\mathrm{NO}_{3}\right)_{2}$ and $\mathrm{Zn}\left(\mathrm{NO}_{3}\right)_{2}$ were coprecipitated using $\mathrm{Na}_{2} \mathrm{CO}_{3}$ aq. as the precipitant at $\mathrm{pH}=6.5$. All precipitation procedures were conducted using a Yamato Kagaku homogenizer. These Pd-Zn and Cu-Cr mixture were mixed, using a Yamato Kagaku kneading apparatus, and reduced in a mixed gas containing $1.7 \% \mathrm{CO}, 3.3 \% \mathrm{H}_{2}$, and $95 \% \mathrm{~N}_{2}$ flowing at a rate of $50 \mathrm{ml} / \mathrm{min}$ and heating at a rate of $1.4^{\circ} \mathrm{C} / \mathrm{min}$ up to $350^{\circ} \mathrm{C}$. Five kinds of catalysts thus prepared were designated M-1 M-5 and listed in Table 1.

\subsection{Preparation of Gomposite Catalysts}

The H-ZSM-5, prepared by the method described in our previous paper11),12), was mixed with a MSC in a porcelain mortar without kneading. The mixture consisted of the same weight of each component. The mixed powder was first tableted then crushed to 8 15 mesh pieces.

\subsection{Gatalyst Characterization}

The temperature programmed reduction (TPR) for MSC was conducted using a TG-DTA apparatus, Shimadzu DTG-30. A $15 \mathrm{mg}$ portion of the catalyst sample was placed in a sample pan. To avoid possible influence of dehydration and/or decomposition of the metal salts on the TPR profile, the sample was heated to $350^{\circ} \mathrm{C}$ in $\mathrm{N}_{2}$ flow. After cooling to room temperature, the sample was heated at a constant rate $\left(2^{\circ} \mathrm{C} / \mathrm{min}\right)$ in a $5 \% \mathrm{H}_{2}$ -
$95 \% \mathrm{~N}_{2}$ mixed gas flow. X-ray powder diffraction analysis with $\mathrm{CuK} \alpha$ radiation was conducted using a Rigaku Geiger-Flex 2013 with a wide source for identification and measurement of crystallite sizes of the catalysts.

\subsection{Reaction Method}

Reaction of methanol and hydrocarbon syntheses from syngas were carried out, usually under $20 \mathrm{~atm}$, using the same flow-reaction apparatus used in our previous work ${ }^{12}$. A $0.5 \mathrm{~m} l$ portion of the catalyst was packed in a stainless steel tublar reactor of 6 $\mathrm{mm}$ i. d.. The ratio of $\mathrm{H}_{2} / \mathrm{CO}$ of the reaction gas was 2 or 1 . The reaction conditions were: $P=$ $20 \mathrm{~atm}, T=220 \sim 340^{\circ} \mathrm{C}$, and $\mathrm{SV}=6,000 \mathrm{~h}^{-1}$. All products were analyzed as gas by TCD- and FIDtype gas chromatographs. Details of liquid-hydrocarbon range were analyzed by an OV-101-coated capillary column using a Shimadzu CR1-B type degital integrator equipped with an FID gaschromatograph.

\section{Results and Discussion}

\subsection{Effects of Pd Loading and Source of $\mathrm{Zn}$ on the TPR Profile and XRD Pattern}

The TPR profiles and their differential curves for each catalyst are shown in Figs. 1 and 2, respectively. The palladium nonloaded sample, M-1, showed a rapid reduction around $150^{\circ} \mathrm{C}$, and a slow and steady reduction above $200^{\circ} \mathrm{C}$. Palladium loaded samples (M-2,3, and 4) were reduced at temperatures lower than these on M-1, and their temperature profiles were monotonous. Figure 2 shows the difference more clearly. Palladium lowered the reduction temperature; however, the temperature at the maximum reduction rate $(\theta \mathrm{m})$ shifted to a higher temperature and the peak was

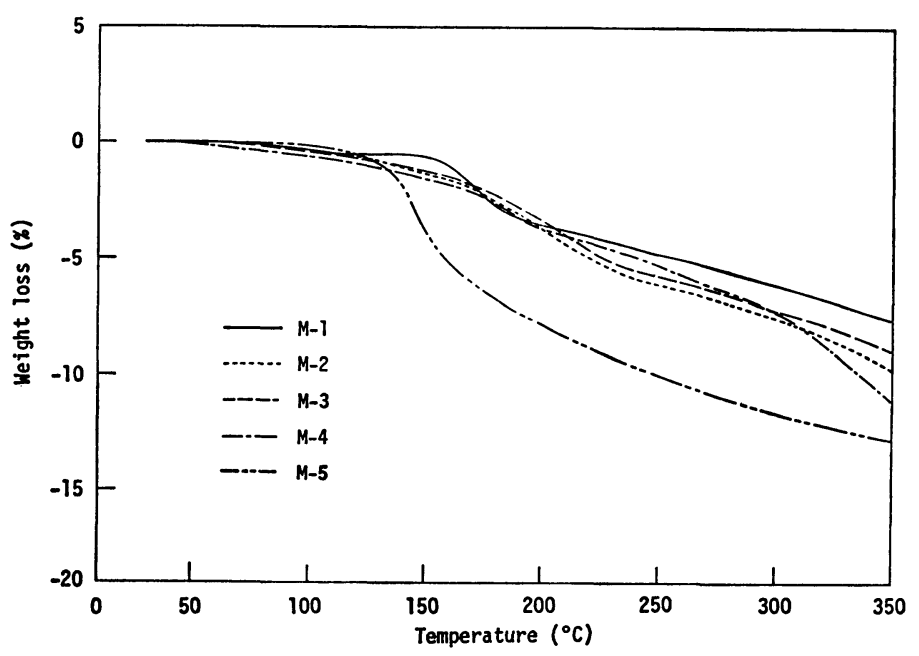

Fig. 1 TPR Profiles for Pd-doped Cu-Cr-Zn Catalysts 


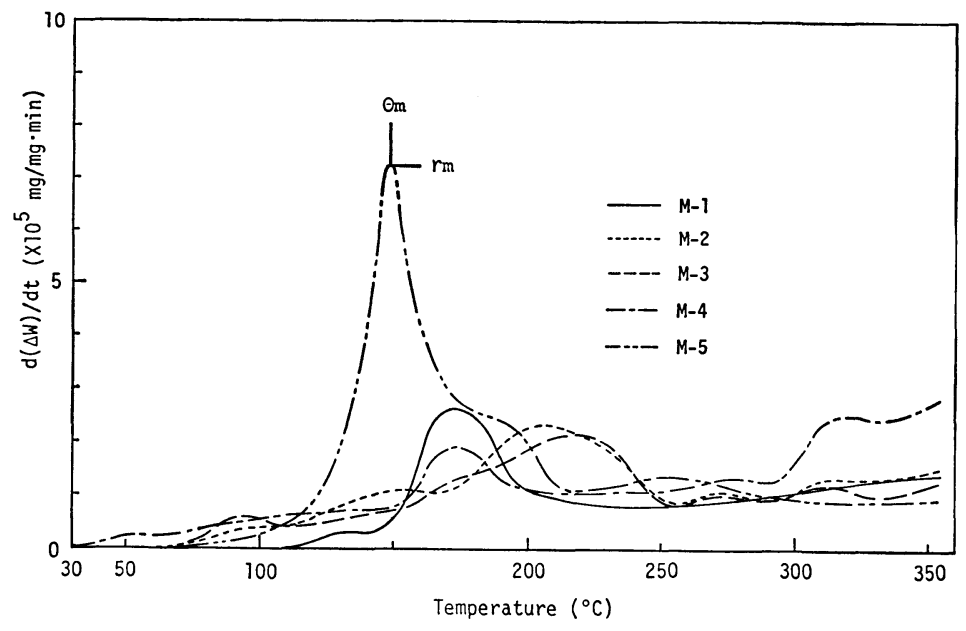

Fig. 2 Differential Curves of TPR Profiles shown in Fig. 1

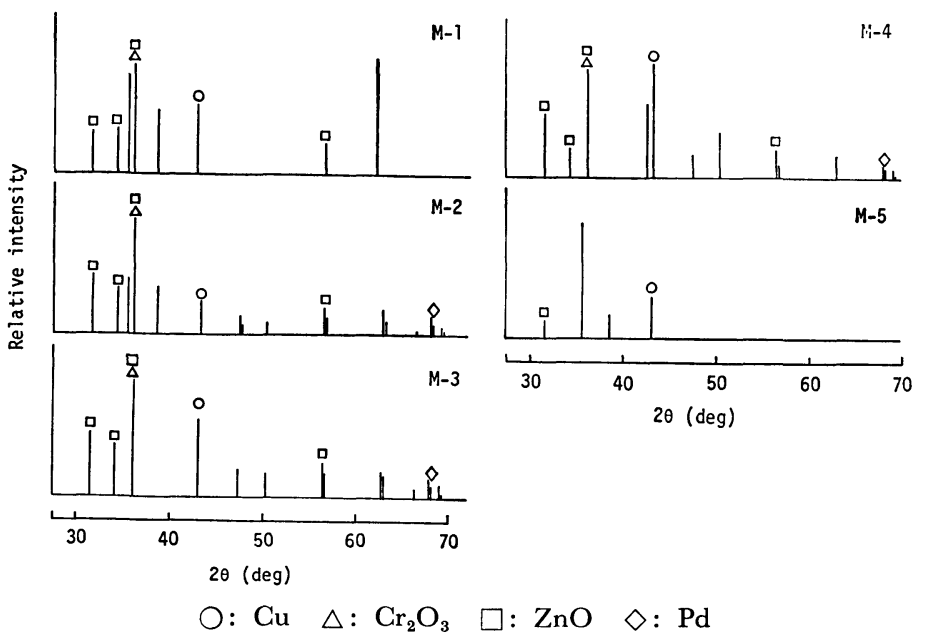

Fig. 3 XRD Pattern for each Pd-doped Cu-Cr-Zn Catalyst after Reduction

broadened. On the other hand, catalyst M-5, in which $\mathrm{Zn}$ source and Pd-loading method were different from those of the others, showed a different temperature profile. The $\theta \mathrm{m}$ was the lowest (150 ${ }^{\circ} \mathrm{C}$ ) and the maximum reduction rate $(\mathrm{rm})$ was the largest $\left(\simeq 7 \times 10^{-5} \mathrm{mg} / \mathrm{mg} \cdot \mathrm{min}\right)$. These observations must reflect that $\mathrm{Pd}$ was dispersed more finely and acted more effectively as a transport agency for hydrogen spillover. The degree of reduction was calculated for each MSC, based on the assumption that $\mathrm{CuO} \cdot \mathrm{CrO}_{3} \cdot \mathrm{ZnO} \cdot \mathrm{PdO}$ was reduced to $\mathrm{CuO}_{X} \cdot \mathrm{Cr}_{2} \mathrm{O}_{3} \cdot \mathrm{ZnO} \cdot \mathrm{Pd}$ during the course of reduction. The results are as follows: $X=0.76$ (M1), 0.46 (M-2), 0.55 (M-3), 0.27 (M-4), and 0.05 (M-5). The values of $X$ for M-4 and M-5 are very low. In such cases, there is possibility that $\mathrm{Cr}_{2} \mathrm{O}_{3}$ and $\mathrm{ZnO}$ can be partly reduced by the action of $\mathrm{Pd}$ even in these lower temperature regions.

Figure 3 shows the XRD patterns of these catalysts. A set of patterns for M-1 M-4 catalysts shows higher crystallinity than that of M-5. In every XRD pattern, the existence of metallic $\mathrm{Cu}$ can be observed. It is noted that the peak of $\mathrm{Cu}$ is low in M-2 and M-5.

\subsection{Effects of Palladium Loading and $\mathrm{Zn}$ Source of MSC on Methanol Synthesis}

The performance of methanol synthesis reaction for the five kinds of MSC was examined. The results are summarized in Table 2. The activity of each catalyst was expressed as space-time yield (STY: $\mathrm{mol} / l \cdot \mathrm{h}$ ). In Fig. 4, the methanol STY was plotted against reaction temperature. When MSC was not doped with Pd (M-1), the maximum $\mathrm{MeOH}$ STY $(3.4 \mathrm{~mol} / l \cdot \mathrm{h})$ was observed at $292^{\circ} \mathrm{C}$. As shown in Fig. 4, all Pd-doped MSC's (M-2 M-5) had higher activity than that of M-1. The temperature profiles of $\mathrm{MeOH}$ STY for Pd-doped MSC's were different from each other, and the maximum $\mathrm{MeOH} \mathrm{STY}(4.9 \mathrm{~mol} / l \cdot \mathrm{h})$ was obtained at $270^{\circ} \mathrm{C}$ by $\mathrm{M}-2$ in which $\mathrm{Pd}$ loading was least. 
Table 2 Performance of Pd-doped $\mathrm{Cu}-\mathrm{Cr}-\mathrm{Zn}$ Catalysts for Methanol Synthesis

\begin{tabular}{|c|c|c|c|c|c|c|c|c|c|c|c|}
\hline \multirow{2}{*}{ Catalyst } & \multirow{2}{*}{$\underset{\left({ }^{\circ} \mathbf{G}\right)}{\text { Temp. Co }}$} & \multirow{2}{*}{$\begin{array}{c}\text { Conv. } \\
(\%)\end{array}$} & \multicolumn{3}{|c|}{$\operatorname{STY}(\mathrm{mol} / l \cdot \mathrm{h})$} & \multicolumn{6}{|c|}{ Selectivity (G-mol\%) } \\
\hline & & & $\mathrm{MeOH}$ & $\mathrm{MeOMe}$ & $\mathrm{CH}_{4}$ & $\mathrm{MeOH}$ & $\mathrm{MeOMe}$ & $\mathrm{CH}_{4}$ & $\mathrm{C}_{2}+$ & $\mathrm{CO}_{2}$ & $\mathrm{MeOH}+\mathrm{MeOMe}$ \\
\hline \multirow{4}{*}{ M-1 } & $(251$ & 4.8 & 2.3 & 0.4 & 0.2 & 46.4 & 16.9 & 4.5 & 3.6 & 28.6 & 63.3 \\
\hline & $\{272$ & 7.7 & 3.0 & 0.5 & 0.4 & 44.0 & 14.8 & 6.0 & 8.8 & 26.4 & 58.8 \\
\hline & 292 & 9.3 & 3.4 & 0.6 & 0.6 & 39.4 & 13.1 & 6.8 & 13.9 & 26.8 & 52.5 \\
\hline & $(248$ & 6.3 & 4.1 & 0.8 & 0.1 & 63.7 & 24.9 & 1.0 & 0.3 & 10.1 & 88.6 \\
\hline \multirow{3}{*}{$M-2$} & $\{270$ & 9.4 & 4.9 & 1.5 & 0.2 & 49.9 & 31.2 & 1.8 & 1.8 & 15.3 & 81.1 \\
\hline & 291 & 10.2 & 3.4 & 1.9 & 0.4 & 32.7 & 36.2 & 3.3 & 5.2 & 22.6 & 68.9 \\
\hline & $(246$ & 5.4 & 3.4 & 0.7 & 0.1 & 62.6 & 26.1 & 1.4 & 1.1 & 8.8 & 88.7 \\
\hline \multirow[t]{3}{*}{$M-3$} & $\left\{\begin{array}{l}270 \\
270\end{array}\right.$ & 8.2 & 3.8 & 1.3 & 0.1 & 49.1 & 34.8 & 1.8 & 1.4 & 12.9 & 83.9 \\
\hline & 298 & 11.1 & 3.6 & 2.1 & 0.4 & 32.9 & 39.2 & 3.4 & 4.2 & 20.3 & 72.1 \\
\hline & $(240$ & 4.9 & 2.7 & 0.6 & 0.1 & 59.3 & 25.0 & 1.2 & 0.3 & 14.2 & 84.3 \\
\hline \multirow[t]{3}{*}{ M-4 } & $\left\{\begin{array}{l}260 \\
265\end{array}\right.$ & 7.5 & 3.7 & 1.0 & 0.1 & 50.1 & 25.3 & 2.1 & 2.3 & 20.2 & 75.4 \\
\hline & 290 & 9.6 & 3.5 & $\begin{array}{l}1.4 \\
\end{array}$ & 0.4 & 35.6 & 28.3 & 3.7 & 6.0 & 26.4 & 63.9 \\
\hline & $(253$ & 7.2 & 4.3 & 0.3 & 0.2 & 68.4 & 10.1 & 3.4 & 3.9 & 14.2 & 78.5 \\
\hline \multirow{2}{*}{ M-5 } & $\{278$ & 9.9 & 4.3 & 0.4 & 0.4 & 51.7 & 10.0 & 5.3 & 10.1 & 22.9 & 61.7 \\
\hline & 295 & 10.3 & 3.9 & 0.6 & 0.7 & 38.7 & 12.0 & 6.4 & 15.9 & 27.0 & 50.7 \\
\hline
\end{tabular}

Reaction conditions : $\mathrm{H}_{2} / \mathrm{CO}=2, \quad P=20 \mathrm{~atm}, \quad \mathrm{SV}=6,000 \mathrm{~h}^{-1}$

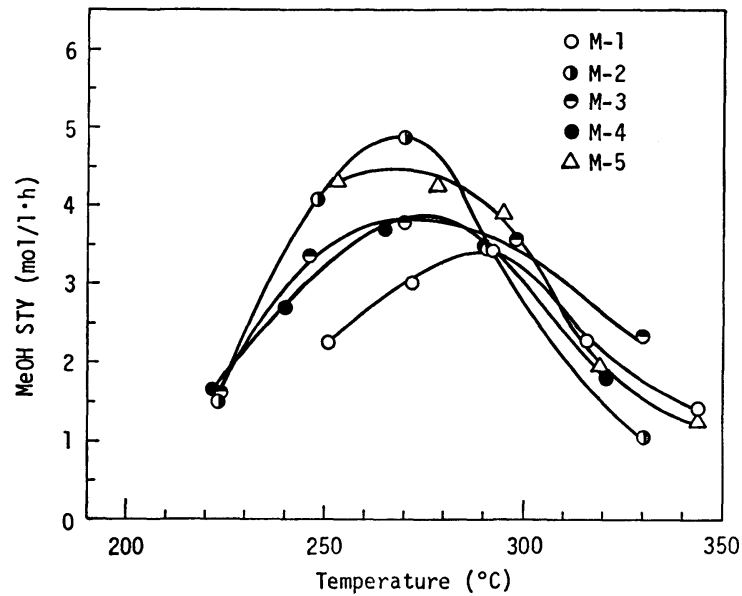

Reaction conditions: $\mathrm{H}_{2} / \mathrm{CO}=2, P=20 \mathrm{~atm}, \mathrm{SV}=6,000$ $\mathrm{h}^{-1}$

Fig. 4 Temperature Dependence of MeOH STY for each Pd-doped $\mathrm{Cu}-\mathrm{Cr}-\mathrm{Zn}$ Catalyst

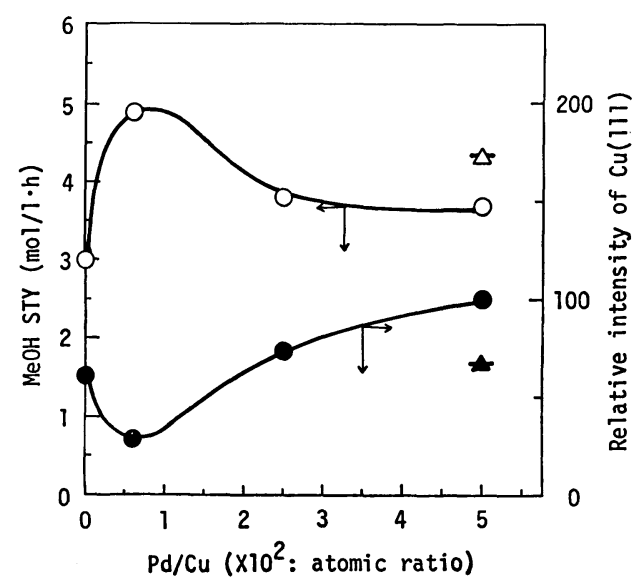

๑: Commercial $\mathrm{ZnO}$ powder was used

$\triangle \Delta$ : Freshly prepared $\mathrm{Zn}(\mathrm{OH})_{2}$ from $\mathrm{Zn}\left(\mathrm{NO}_{3}\right)_{2}$ was used. Reaction conditions: $\mathrm{H}_{2} / \mathrm{CO}=2, P=20 \mathrm{~atm}$, $T=270 \pm 5^{\circ} \mathrm{C}, \mathrm{SV}=6,000 \mathrm{~h}^{-1}$

Fig. 5 Effect of the Amount of Pd on the MeOH STY and $\mathrm{Cu}(111)$ Peak Intensity of XRD
Moreover, $\mathrm{CO}_{2}$ selectivity was considerably lower at that temperature. When, in stead of using $\mathrm{ZnO}$ powder (M-4), $\mathrm{Zn}$ and $\mathrm{Pd}$ components were simultaneously incorporated into $\mathrm{Cu}-\mathrm{Cr}$ mixed oxides by coprecipitation (M-5), as described in the experimental section, MeOH STY increased especially at lower temperatures. The highly active catalysts M-2 and M-5 showed low oxidation states as mentioned above. Relative intensities of $\mathrm{Cu}(111)$ and $\mathrm{MeOH}$ STY were plotted against $\mathrm{Pd} / \mathrm{Cu}$ atomic ratio (Fig. 5). Since the $\mathrm{XRD}$ peak of $\mathrm{Cu}_{2} \mathrm{O}$ was masked by $\mathrm{Cu}$ peak ${ }^{16)}$, the $\mathrm{Cu}$ peak intensity was adopted as the index of $\mathrm{Cu}$ reduction state. Figure 5 shows inverse corelation between intensity and $\mathrm{MeOH}$ STY, and the maximum MeOH STY was obtained by low Pd loading; it also showed that when freshly prepared $\mathrm{Zn}(\mathrm{OH})_{2}$ from $\mathrm{Zn}\left(\mathrm{NO}_{3}\right)_{2}$ was used as $\mathrm{Zn}$ source, the catalyst exhibited a better performance than when commercial $\mathrm{ZnO}$ was used.

\subsection{Activity of Pd-doped Gu-Gr-Zn/H-ZSM-5 Composite Catalysts for Syngas Conver- sion}

Each of the Pd-doped Cu-Cr-Zn catalysts (M-2 M-5) mixed with an equivalent weight of H-ZSM5 was ground in a porcelain mortar to a fine powder which was tableted then crushed to $8 \sim 15$ mesh pieces for use.

Hydrocarbon-synthesis activities of these composite catalysts are expressed as space-time conversion $\left(\mathrm{STC}_{\mathrm{HC}} \mathrm{mol} / l \cdot \mathrm{h}\right)$ of $\mathrm{CO}$, and shown in Fig. 6. Carbon monoxide STC for hydrocarbon formation was calculated from all hydrocarbons produced. For a set of composite catalysts whose $\mathrm{Zn}$ component was derived from commercial $\mathrm{ZnO}$ powder (desingated as $\mathrm{MZ}-1 \sim \mathrm{MZ}-4$ ), the $\mathrm{CO} \mathrm{STC}_{\mathbf{H C}}$ 


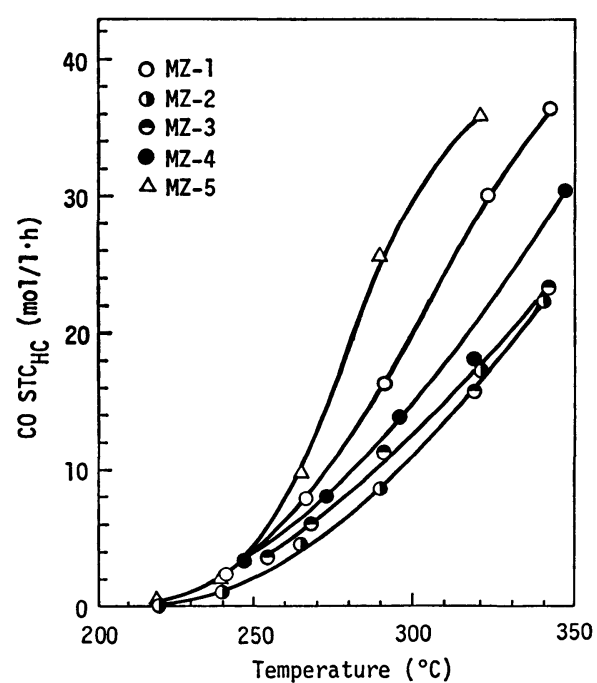

Reaction conditions: $\mathrm{H}_{2} / \mathrm{CO}=2, P=20 \mathrm{~atm}, \mathrm{SV}=6,000$ $\mathrm{h}^{-1}$

Fig. 6 Temperature Dependence of CO STC to Hydrocarbons for each Composite Catalyst

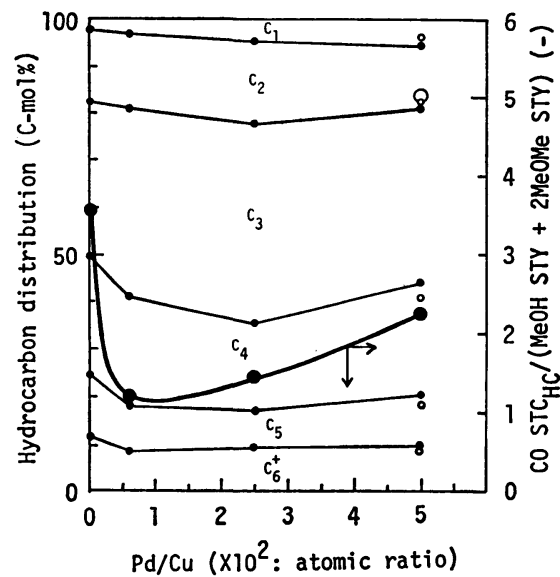

0: Commercial $\mathrm{ZnO}$ powder was used

$\mathrm{O}$ : Freshly prepared $\mathrm{Zn}(\mathrm{OH})_{2}$ from $\mathrm{Zn}\left(\mathrm{NO}_{3}\right)_{2}$ was used Reaction conditions: $\mathrm{H}_{2} / \mathrm{CO}=2, P=20 \mathrm{~atm}, T=270 \pm 5$ ${ }^{\circ} \mathrm{C}, \mathrm{SV}=6,000 \mathrm{~h}^{-1}$

Fig. 7 Effect of the Amount of Pd on Hydrocarbon Distribution and $\mathrm{CO}$ STC/(MeOH STY+2 MeOMe STY)

decreased by Pd addition in the MSC and had a minimum at $\mathrm{Pd} / \mathrm{Cu}$ concentration 0.006 (MZ-2). Although the effect of Pd on MSC catalysts M-2 M-5 was positive for methanol synthesis, it was negative for hydrocarbon synthesis when $\mathrm{Pd}$ was combined with H-ZSM-5. On the other hand, the composite catalyst whose $\mathrm{Zn}$ component was derived from $\mathrm{Zn}\left(\mathrm{NO}_{3}\right)_{2}$ (MZ-5) showed the highest $\mathrm{CO} \mathrm{STC}_{\mathrm{HC}}$ in spite of its high Pd content.

In Fig. 7, the effects of Pd content of MSC on the distribution of hydrocarbons produced and $\mathrm{CO}$ $\mathrm{STC}_{\mathrm{HC}} /(\mathrm{MeOH} \mathrm{STY}+2 \mathrm{MeOMe} \mathrm{STY})$ are shown, where the space-time yields of $\mathrm{MeOH}$ and $\mathrm{MeOMe}$ were obtained on the methanol synthesis catalysts (M-1 M-5) in the absence of H-ZSM-5, and CO STC $_{\mathrm{HC}}$ was obtained on the composite catalysts (MZ-1 MZ-5), Therefore, the value of this ratio can be regarded as the index for estimating the nontrivial polystep mechanism proposed by Weisz ${ }^{\mathbf{1 4})}$. As for hydrocarbon distribution, $\mathrm{C}_{4}^{+}$hydrocarbons decreased and ethane and propane increased and aromatics were negligible for all catalysts by addition of a small amount of $\operatorname{Pd}(\simeq 0.006 \mathrm{Pd} / \mathrm{Cu}$, atomic ratio). As has already been pointed out by Fujimoto et al. that olefin-lean feature of the hydrocarbons produced in the syngas conversion on $\mathrm{Cu}$ $\mathrm{Zn}-\mathrm{Al} / \mathrm{H}-\mathrm{ZSM}-5^{8)}$ and $\mathrm{Pd} / \mathrm{SiO}_{2} / \mathrm{H}-\mathrm{ZSM}-5^{9}$ ) would be attributed to the hydrogenation by metal oxide or by metal components of the composite catalysts. It was proved that Pd brought about both methanol synthesis activity and olefin hydrogenation activity.

As shown in Fig. 7, CO $\mathrm{STC}_{\mathrm{HC}} /(\mathrm{MeOH} \mathrm{STY}+$ $2 \mathrm{MeOMe} \mathrm{STY}$ ) had a minimum at $\mathrm{Pd} / \mathrm{Cu}$ concentration $=0.006 \quad(\mathrm{MZ}-2)$, and this suggests that $\mathrm{Pd}$ inhibits hydrocarbon formation. This phenomenon can be considered as the suppression of autocatalytic conversion jump of $\mathrm{MeOH}^{17)}$ on H-ZSM5 because of the decrease in the concentration of surface olefinic precursors owing to hydrogenation caused by addition of Pd, especially in low concentrations.

\subsection{Effect of O-R Treatment of Pd-doped Cu- Gr-Zn/H-ZSM-5 Composite Catalyst on Syngas Conversion}

The results so far obtained have proved that excessive increase in the methanol-synthesis activity of MSC by Pd addition in the composite catalyst rather inhibits the carbon chain growth and lowers CO STC $_{\text {HC. }}$.

It was previously reported that $\mathrm{O}-\mathrm{R}$ treatment performed on a Pd-doped Zn-Cr MSG/H-ZSM-5 composite catalyst increased gasoline selectivity. ${ }^{12)}$ Therefore, O-R treatment was first performed on MSC (M-5), then the treated M-5 was combined with H-ZSM-5 by mixing. The reduction temperature for O-R treatment was $600^{\circ} \mathrm{C}$ (Exp. 2 in Table 3). Compared with the results of untreated catalyst Exp. 1, C. selectivity increased by about $9 \%$ although $\mathrm{CO}$ conversion decreased by about $10 \%$.

Next, the O-R treatment was performed on premixed catalysts of MSC (M-5) and H-ZSM-5 with the same conditions (Exp. 3). As a result, CO conversion further decreased by $5 \%$, however, $\mathrm{C}_{4}^{+}$ 


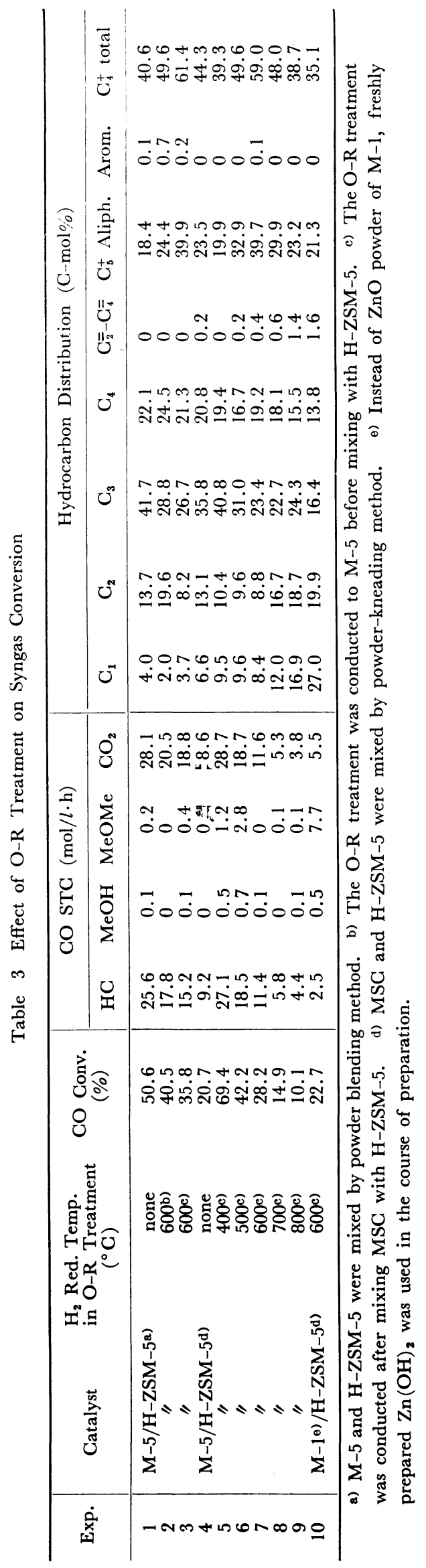

selectivity increased up to $61.4 \%$; the space-time conversion of $\mathrm{CO}$ to $\mathrm{C}_{4}^{+}($Exp. 3, $9.5 \mathrm{~mol} / l \cdot \mathrm{h})$ was almost the same as that of the untreated catalyst (Exp. 1, $10.4 \mathrm{~mol} / l \cdot \mathrm{h}$ ). These results suggest that a strong interaction between MSC and H-ZSM-5 has been brought about by O-R treatment.

To further investigate this interaction, MSC and H-ZSM- 5 were mixed by kneading thoroughly in a mortar, and the effects of reduction temperature in the range from 400 to $800^{\circ} \mathrm{C}$ (Exp. 5 9) were investigated. By such kneading, $\mathrm{CO}$ conversion of untreated catalyst was lowered from 50.6\% (Exp. 1) to $20.7 \%$ (Exp. 4). The CO conversion was maximum at the reduction temperature of $400^{\circ} \mathrm{C}$ (Exp. 5), and it was lower than that of the untreated catalyst above $700^{\circ} \mathrm{C}$. Reduction at $600^{\circ} \mathrm{C}, \mathrm{C}_{4}^{+}$ selectivity was maximum (59.0\%). For comparison $\mathrm{O}-\mathrm{R}$ treatment was conducted for non-Pd loaded Cu-Cr-Zn catalyst (Exp. 10), whose source of $\mathrm{Zn}$ component was $\mathrm{Zn}\left(\mathrm{NO}_{3}\right)_{2}$. Its $\mathrm{CO} \mathrm{STC}_{\mathrm{HC}}$ was very low, and the principal product was dimethyl ether. This suggests that the acidity of composite catalyst was lowered by redox-treatment more in the absence of $\mathrm{Pd}$ than in its presence. It seems reasonable to consider that, in the presence of $\mathrm{Pd}$, the oxidation state of the mixed oxides, even that of $\mathrm{ZnO}$, was reduced at such high temperature as $600^{\circ} \mathrm{C}$ by hydrogen spillover resulting in a lower basicity of the mixed oxides. On the other hand, when Pd was absent, the oxidation state of the mixed oxides, especially that of $\mathrm{ZnO}$, was maintained at a higher level; thus the basicity of the mixed oxides, principally due to $\mathrm{ZnO}$, would neutralize the acidity of the zeolite particle surface by thorough kneading.

In Fig. 8, X-ray diffraction patterns of these catalysts are shown. It is remarkable that peak intensities in the vicinity of $2 \theta=30,35,43,50$, and 63 degree increased and became sharp with increasing reduction temperature. In Fig. 9, the relations involving reduction temperature, the average crystallite size of MSC components, and the selectivity of $\mathrm{C}_{*}^{+}$fraction are shown. This figure indicates that $\mathrm{C}_{4}^{+}$selectivity increased with increasing $\mathrm{CuCr}_{2-}$ $\mathrm{O}_{4}$ crystallite size or with reduction temperature up to $600^{\circ} \mathrm{C}$. However, above that temperature $\mathrm{C}_{4}^{+}$ selectivity decreased because the crystallite size of $\mathrm{CuCr}_{2} \mathrm{O}_{4}$ was reduced due probably to the separation of $\mathrm{Cu}$ phase.

Carbon number distributions of hydrocarbons produced by untreated and O-R treated $\left(600^{\circ} \mathrm{C}\right)$ catalysts are plotted in Fig. 10. By O-R treatment, 


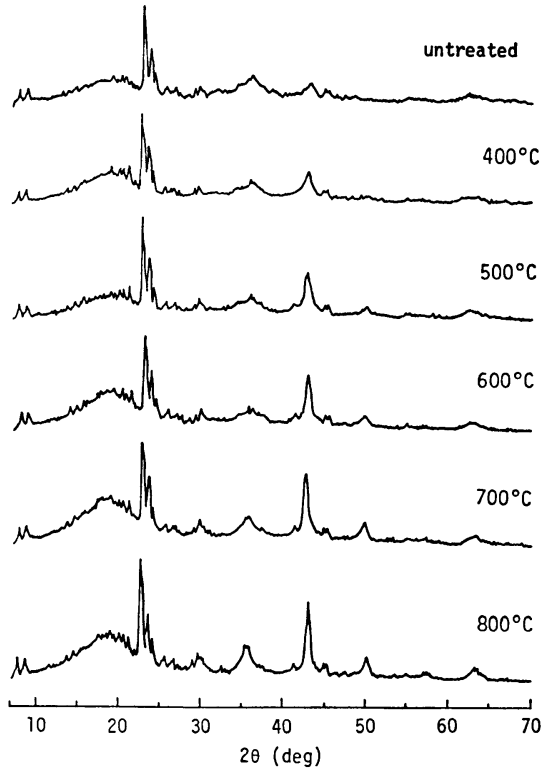

Fig. 8 Effect of $\mathrm{H}_{2}$-reduction Temperature of O-R Treatment on the XRD Patterns of $\mathrm{M}-5 / \mathrm{H}$ ZSM-5 Catalyst

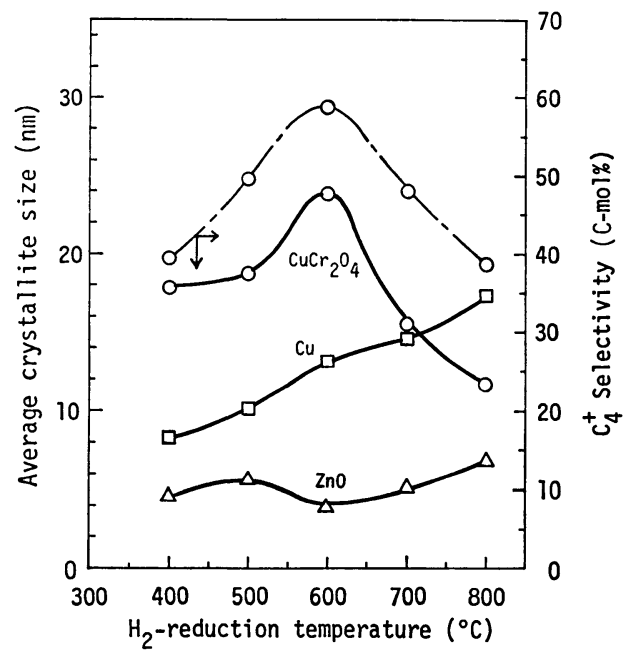

Catalyst: M-5/H-ZSM-5

Reaction conditions: $\mathrm{H}_{2} / \mathrm{CO}=2, P=20 \mathrm{~atm}, T=290^{\circ} \mathrm{C}$, $\mathrm{SV}=6,000 \mathrm{~h}^{-1}$

Fig. 9 Effect of the Reduction Temperature of O-R Treatment on the Average Crystallite Size and $\mathrm{C}_{4}+$ Selectivity

$\mathrm{C}_{2}$ and $\mathrm{C}_{3}$ hydrocarbons decreased and the gasoline fraction increased. Furthermore, as can be seen in Exp. 5 9 of Table 3, the selectivity of lower olefins increased with increasing reduction temperature for the O-R treated.

This indicates that hydrogenation activity due to $\mathrm{Pd}$ and mixed oxides decreases because of sintering or recrystallization by $\mathrm{O}-\mathrm{R}$ treatment. This trend is enhanced by lowering the $\mathrm{H}_{2} / \mathrm{CO}$ ratio from 2 to 1; and as shown in Table 3, small amounts of

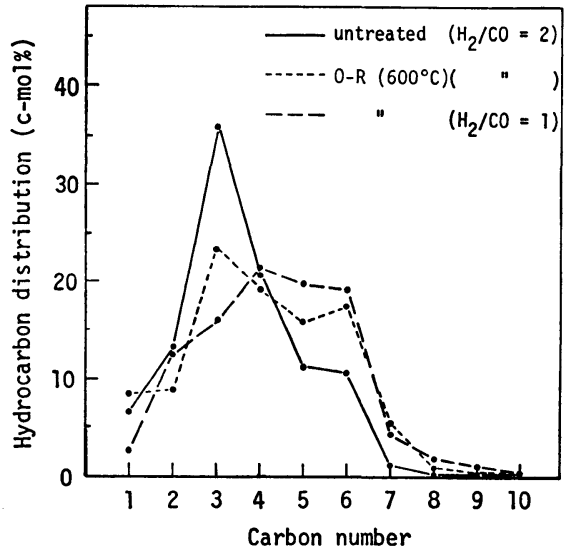

Catalyst: M-5/H-ZSM-5

Reaction conditions: $P=20 \mathrm{~atm}, T=290^{\circ} \mathrm{C}, \mathrm{SV}=6,000$ $h^{-1}$

Fig. 10 Effect of O-R Treatment and $\mathrm{H}_{2} / \mathrm{CO}$ Ratio on Hydrocarbon Distribution

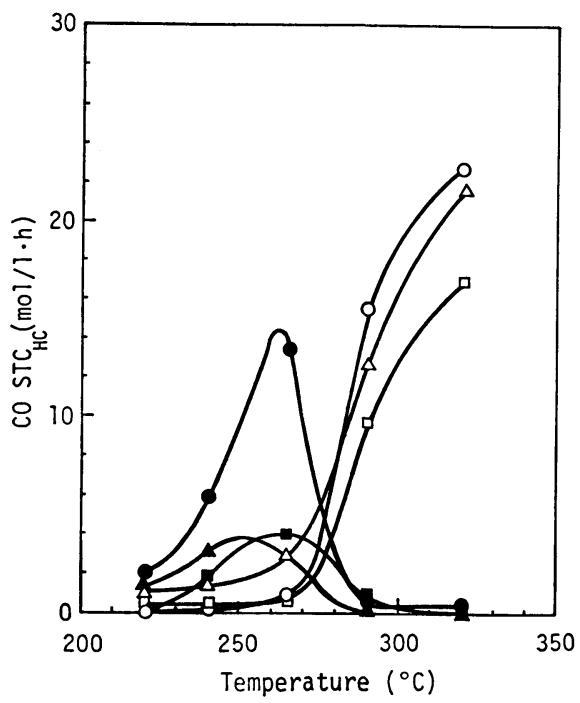

Additives: circle, none; triangle, $4.9 \% \mathrm{C}_{2} \mathrm{H}_{4}$; square, 2.9 $\% \mathrm{CO}_{2}$

Open symbol: Hydrocarbon, Filled symbol: $\mathrm{MeOMe}$ Reaction conditions: $\mathrm{H}_{2} / \mathrm{CO}=2, P=20 \mathrm{~atm}, \mathrm{SV}=6,000$ $\mathrm{h}^{-1}$

Fig. 11 Effects of Additives on Syngas Conversion

lower olefins were produced by O-R treatment. Thus, suppression of lower-olefin hydrogenation is considered to be effective for increasing $\mathrm{C}_{4}^{+}$selectivity. The $\mathrm{C}_{4}^{+}$hydrocarbons were mostly branched.

\subsection{Effect of Gaseous Additives on Syngas Conversion}

Krier et al. 18) reported that a small amount of $\mathrm{CO}_{2}$ remarkably accelerated the formation of methanol from syngas. It was also reported that lower olefins and several alcohols accelerated methanol conversion on H-ZSM-5 zeolite. ${ }^{17), 19), 20)}$ The au- 
Table 4 Effect of Small Amount of Additives on the Products of Syngas Conversion

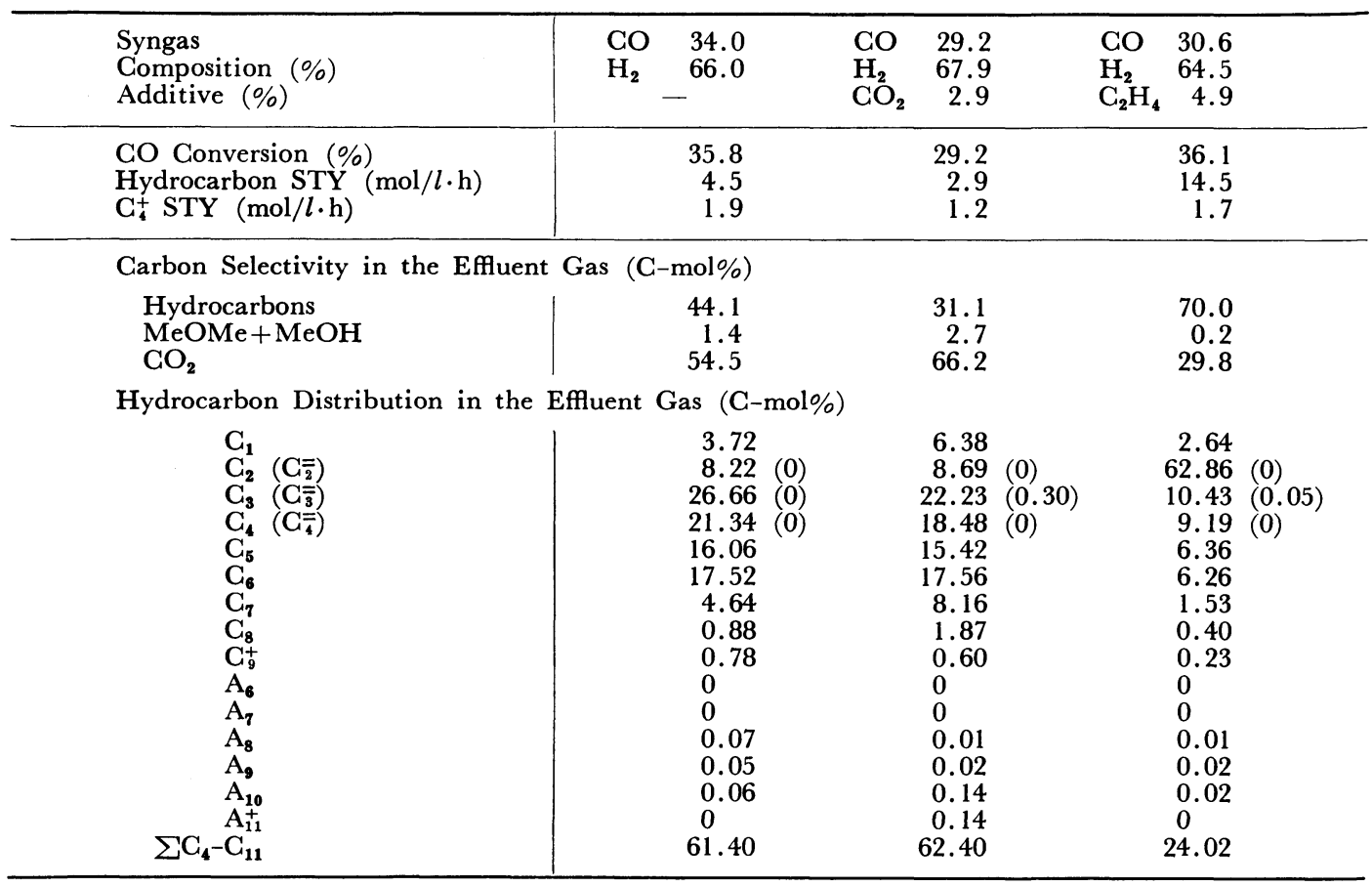

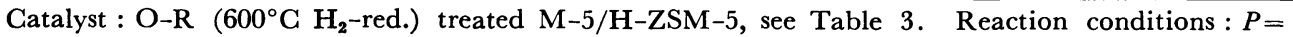
$20 \mathrm{~atm}, T=290^{\circ} \mathrm{C}, \quad \mathrm{SV}=6,000 \mathrm{~h}^{-1}$

thors ${ }^{21)}$ found that the addition of a small concentration of $\mathrm{C}_{2}^{+}$alcohols not only accelerated methanol conversion on H-ZSM-5, but also increased gasoline selectivity. It is of interest to apply these observations to syngas conversion on the composite catalyst to increase liquid hydrocarbon yields. Hence, syngas conversion was carried out by adding a small amount of $\mathrm{C}_{2} \mathrm{H}_{4}(4.9 \%)$ or $\mathrm{CO}_{2}(2.9$ $\%$ ). The results obtained at $290^{\circ} \mathrm{C}$ are listed in Table 4, and the space-time conversion of $\mathrm{CO}$ to hydrocarbons and dimethyl ether are plotted against reaction temperature in Fig. 11. In the case of $\mathrm{CO}_{2}$ addition, only retardation in $\mathrm{CO}$ $\mathrm{STC}_{\mathrm{HC}}$ occurred, and slight increases in $\mathrm{C}_{7} \sim \mathrm{C}_{8}$ paraffinic hydrocarbons and $\mathrm{C}_{10}^{+}$aromatics were observed. In the case of $\mathrm{C}_{2} \mathrm{H}_{4}$ addition, $\mathrm{C}_{2} \mathrm{H}_{4}$ was hydrogenated completely to $\mathrm{C}_{2} \mathrm{H}_{6}$ even at $220^{\circ} \mathrm{C}$. At such low temperature, $\mathrm{CO}$ conversion was below $5 \%$; therefore $\mathrm{CO} \mathrm{STC}_{\mathrm{HC}}$-expecting $\mathrm{C}_{2} \mathrm{H}_{6}$-was calculated. Moreover, enhancement in $\mathrm{CO} \mathrm{STC}_{\mathrm{HC}}$ was observed only below $280^{\circ} \mathrm{G}$.

\section{Conclusions}

For syngas conversion to hydrocarbons on composite catalysts of Pd-doped Cu-Cr-Zn/H-ZSM-5 at low temperatures - below $300^{\circ} \mathrm{C}$ - the following conclusions were obtained.

(1) The space-time yield of $\mathrm{MeOH}$ of MSC $(\mathrm{Cu}-\mathrm{Cr}-\mathrm{Zn})$ increased from 3.0 to $4.9 \mathrm{~mol} / l \cdot \mathrm{h}$ at $270^{\circ} \mathrm{C}$ by doping it with a small amount $(0.4 \%)$ of $\mathrm{Pd}$ with maintained the proper reduction state of the catalyst during reaction.

(2) For hydrocarbon formation, the $\mathrm{Zn}$ component of the composite catalyst derived from freshly prepared $\mathrm{Zn}(\mathrm{OH})_{2}$ was more effective than that derived from commercial $\mathrm{ZnO}$ powder.

(3) By O-R treatment performed at $600^{\circ} \mathrm{C}, \mathrm{C}_{3}$ hydrocarbon formation decreased, and the hydrocarbon distributions shifted to higher carbon numbers.

(4) The O-R treatment performed on the composite catalyst at $600^{\circ} \mathrm{C}$ enhanced its activity for production of liquid hydrocarbons $\left(\mathrm{C}_{\mathbf{4}} \sim \mathrm{C}_{11}\right)$. The space-time yield and selectivity of the liquid hydrocarbons were $9.5 \mathrm{~mol} / l \cdot \mathrm{h}$ and $61.4 \mathrm{C}-\mathrm{mol} \%$, respectively, under the following conditions: $\mathrm{H}_{2} / \mathrm{CO}$ $=2,20 \mathrm{~atm}, \mathrm{SV} 6,000 \mathrm{~h}^{-1}$, and $290^{\circ} \mathrm{C}$.

\section{Acknowledgement}

This research was supported by the Grant for Scientific Research in Effective Use of Energy (Grant No. 58040014) from the Ministry of Education of Japan.

\section{References}

1) Meisel, S. L., McCullough, J. P., Lechthaler, C. H., Weisz, P. B., Chemtech, 6, 86 (1976).

2) U. S. $3,894,106$.

3) U. S. $3,894,107$.

4) U. S. $3,928,483$. 
5) Chang, C. D., Lang, W. H., Silvestri, A. J., J. Catal., 56, 268 (1979).

6) Ione, K. G., Yegorova, L. S., Orlova, L. B., 6th JapanSoviet Catalysis Seminar, Osaka, Preprints, 180 (1981).

7) Inui, T., Takegami, Y., ACS Div. Petrol. Chem. Preprints, 27, 982 (1982).

8) Fujimoto, K., Kudo, Y., Tominaga, H., Nippon Kagaku Kaishi, 206 (1982).

9) Fujimoto, K., Kudo, Y., Tominaga, H., Proc. PanPacific Synfuel Conference, 1, 123 (1982).

10) Yashima, T., Yoshimura, A., Wakushima, Y., Namba, S., Proc. Pan-Pacific Synfuel Conference, 1, 130 (1982).

11) Inui, T., Takegami, Y., Proc. Pan-Pacific Synfuel Conference, 1, 145 (1982).

12) Inui, T., Hagiwara, T., Takegami, Y., Sekiyu Gakkaishi, 27, 228 (1984).
13) Fujimoto, K., Kudo, Y., Tominaga, H., J. Catal., 87, 136 (1984)

14) Weisz, P. B., Adv. Catal., 13, 137 (1962).

15) Iwabuchi, N., Terao, I., Uda, A., Kuraishi, M., Shokubai(Catalyst), 4, (4), 379 (1962).

16) Himelfarb, P. B., Wawner, F. E., Bieser, A. J., Vines, S. N., J. Catal., 83, 469 (1983).

17) Chen, H. Y., Regan, W. J., J. Catal., 59, 123 (1979).

18) Krier, K., Chatikavanij, V., Herman, R. G., Simmons, G. W., J. Catal., 74, 343 (1982).

19) Ono, Y., Mori, T., J. Chem. Soc., Faraday Trans 1, 77, 2209 (1981).

20) Langner, B. E., Appl. Catal., 2, 289 (1982).

21) Inui, T., Hagiwara, T., Tarumoto, J., Sekiyu Gakkaishi, under contribution.

要旨

\section{パラジゥムで修飾した銅ークロム-亜鉛複合酸化物ならびに H-ZSM-5 からなる 複合触媒による合成ガスからの液状炭化水素の低温合成}

乾 智行, 萩原 隆, 山瀬 修, 北川賀津一, 山口裕樹, 武上善信

京都大学工学部石油化学教室, 606 京都市左京区吉田本町

形状選択性ゼオライト ZSM-5 とメタノール合成触媒との 複合触媒を用いて合成ガスから直接液状炭化水素を選択的に合 成する反応は, 通常三百数十 ${ }^{\circ} \mathbf{C}$ 以上の比較的高温と高圧の条 件域で検討されてきた。しかし，このような温度域の場合，メ タノール合成収量には限界があり, したがって液状炭化水素の 収量もあまり高くできない。そこで本研究では, メタノール合 成に有利な $300^{\circ} \mathrm{C}$ 以下の低温域で選択的に高収率で液状炭化 水素を合成することを目的として, Pd で修飾した $\mathrm{Cu}-\mathrm{Cr}-\mathrm{Zn}$ 複合酸化物からなる低温型メタノール合成触媒と低温でも×タ ノール変換能をもつ高活性 H-ZSM-5 とを組合わせた触媒に ついて, $20 \mathrm{~atm}$ 下での流通法によって合成ガスの転化反応を 検討した。

まず, メタノール合成触媒の TPR 挙動に対する触媒成分 の影響を調べた。市販の $\mathrm{ZnO}$ に硝酸パラジウムを含浸させた 場合はPd の添加により還元開始温度は低くなったが，還元 速度が最大となる 温度はむしろ高く $\left(200 \sim 220^{\circ} \mathrm{C}\right)$ なった。 $\mathrm{Zn}\left(\mathrm{NO}_{3}\right)_{2}$ と $\mathrm{Pd}\left(\mathrm{NO}_{3}\right)_{2}$ の混合溶液から $\mathrm{Na}_{2} \mathrm{CO}_{3}$ で沈殿さ せて得た $\mathrm{Zn}(\mathrm{OH})_{2}-\mathrm{Pd}(\mathrm{OH})_{2}$ を用いた場合には, $150^{\circ} \mathrm{C}$ の低 温から急激に還元が起こり，還元量も最大となった（Figs. 1,
2)。これらの触媒のメタノール合成活性は Pd 添加量が小さ い場合 $(\mathrm{Pd} / \mathrm{Cu}$ 原子比 $=0.006)$ 飞最大となった (Table 2, Fig. 4)。メタノール合成触媒と H-ZSM-5 との複合触媒によ る合成ガスからの炭化水素合成活性は，上記のようにして得た $\mathrm{Zn}(\mathrm{OH})_{2}-\mathrm{Pd}(\mathrm{OH})_{2}$ を用いたものが最も高かった(Fig. 6)。 さらにこの触媒を酸化-還元すると生成物の選択率は変化 し, $400^{\circ} \mathrm{C}$ で酸化, $600^{\circ} \mathrm{C}$ で水素還元した場合に, 液状炭化水素の 選択率は最大 $(61.4 \%)$ となった（Table 3)。酸化-還元処理 条件に対応して $\mathrm{CuCr}_{2} \mathrm{O}_{4}$ の粒子径が変化し, 液状炭化水素の 選択率とよく対応した（Fig. 9)。酸化-還元処理によりとくに プロパンが著しく減少して炭素数分布は高炭素数側 $\left(\mathrm{G}_{5} \sim \mathrm{G}_{9}\right)$ に移動した。この傾向は $\mathrm{H}_{2} / \mathrm{CO}$ 比を 2 から 1 に下げたときさ らに明りょらに認められた（Fig. 10)。

原料の合成ガスに少量の $\mathrm{CO}_{2}$ または $\mathrm{C}_{2} \mathrm{H}_{4}$ を添加したとこ ろ, どちらの場合も $280^{\circ} \mathrm{C}$ 以下でのジメチルェーテルの生成 が大きく抑制された。 $\mathrm{CO}_{2}$ 添加の場合は単に反応抑制的な作 用であったが， $\mathrm{C}_{2} \mathrm{H}_{4}$ 添加の場合は炭化水素生成に対する促進 的効果が認められた（Fig. 11, Table 4)。

\section{Keywords}

Composite catalyst, Hydrocarbon synthesis, Mixed oxide, Palladium, Syngas conversion, Zeolite 